\title{
IMPACT OF GRANULES FROM CRUSHED EXPANDED POLYSTYRENE PACKAGE ON PROPERTIES OF THERMO-INSULATING PLASTER
}

\author{
Jurga ŠEPUTYTĖ-JUCIKĖ, Georgij Arsenij SEZEMAN, Marijonas SINICA, \\ Modestas KLIGYS, Saulius VAITKUS \\ Scientific Institute of Thermal Insulation, Vilnius Gediminas Technical University, \\ Linkmenu g. 28, 08217 Vilnius, Lithuania
}

Received 05 Mar 2014; accepted 22 Apr 2014

\begin{abstract}
The paper deals with the use of lightweight porous aggregate, i.e. crushed expanded polystyrene package crumbs (EPSC) in the composition of thermo-insulating plaster. Its effectiveness is compared to that of spherical granules of expanded polystyrene - white coloured (EPS) and grey coloured (NEOPOR). The content of lightweight aggregate changed from 1.25 to $1.75 \mathrm{l} / \mathrm{kg}$ of dry mix. The investigation focused on properties of modified plaster, such as density, compressive strength, thermal conductivity and water vapour permeability. It was established that EPSC reduce density of plaster from 1350 to $530 \mathrm{~kg} / \mathrm{m}^{3}$, improving such properties as thermal conductivity and water vapour permeability but decreasing compressive strength. In addition, the paper established the adhesion force of plaster (content of lightweight aggregate was $1.25 \mathrm{l} / \mathrm{kg}$ of dry mix) to ceramics, silicate and autoclaved aerated concrete masonry elements. The character of macrostructure of plaster was considered, as well as bonding with a coat of decorative paint. It was found that plaster with EPSC has similar properties to plasters with EPS and NEOPOR aggregates; however, in case of EPSC, the relative vapour resistance is better. The provided regression equations can be used for prediction of differently modified plasters.
\end{abstract}

Keywords: indoor plaster, density, compressive strength, thermal conductivity coefficient, relative vapour resistance, adhesion force, macrostructure.

Reference to this paper should be made as follows: Šeputytė-Jucikè, J.; Sezeman, G. A.; Sinica, M.; Kligys, M.; Vaitkus, S. 2014. Impact of granules from crushed expanded polystyrene package on properties of thermo-insulating plaster, Journal of Civil Engineering and Management 20(4): 581-589. http://dx.doi.org/10.3846/13923730.2014.922492

\section{Introduction}

Coating of masonry surfaces with plaster may be problematic due to incompatibility between enclosure components. It is desirable that components of enclosures, such as bearing masonry, a layer of thermo-insulating material and finishing plasters, would ensure the highest possible value of thermal resistance and sufficient water vapour permeability, and guarantee a stable bond between the components. Interior plasters are additionally required to insulate the interior wall surface, i.e. relatively heavy and cold building elements, such as silicate or concrete blocks and ferroconcrete walls, should be coated with a layer that has lower density and better thermo-insulating properties.

The density of building materials including plasters can be reduced in several ways, e.g. using lightweight aggregates with thermo-insulating properties (Mikulskiy et al. 2007; Ries 2008); and porizing - expanding the aggregate-linking matrix by air; or applying both methods together - expanding the matrix of a composite and using lightweight aggregates (Sinica et al. 2005, 2008).

The most common method is the use of lightweight aggregates, e.g. such inorganic aggregates as expanded perlite (Sari, Karaipeikli 2008; Topcu, Isikdag 2008), vermiculite (Koksal et al. 2012) and granulated foam glass (Limbachiya et al. 2012), which are produced by heating and simultaneously expanding raw materials at a respective temperature; and artificial aggregates of organic origin, such as rubber granules and crumbs (Herrero et al. 2013), foam polyurethane and extruded polystyrene (Gutierrez-Gonzalez et al. 2012; Davraz et al. 2011).

Autoclaved (Ungkoon et al. 2007) and nonautoclaved (Narayanan, Ramamurthy 2000) aerated concretes should be emphasised among products of porous structure. In this case, porous structure is formed with the help of gasifiers and foamers. It should also be noted that aerated concretes, produced using these both methods can result in a reduced density of up to $300 \mathrm{~kg} / \mathrm{m}^{3}$ (Ramamurthy, Narayanan 2000).

Recently, the use of secondary raw materials in production has become a particularly urgent problem (Ducman, Mirtič 2011; Demirboga, Kan 2012). Our case involves expanded polystyrene plates formerly used for thermal insulation of enclosures and expanded polystyrene packaging waste. There are known cases of the use of this crushed waste for production of thermo-insulating composites and their properties have been investigated. 
This paper focuses on investigation of EPSC as a component used in the production of thermo-insulating plaster, aiming to establish the impact of the aggregate on physical properties of plaster and estimate changes in structure that would substantiate the obtained data. For comparison, the paper also provides results of investigations on the impact of other spherical granules of expanded polystyrene (EPS and NEOPOR) on properties of plaster.

\section{Materials and methods}

Dry plaster mixes were prepared under laboratory conditions. Next, the paper presents materials used for this purpose. Sand came from the quarry Giraite in Varena District, Lithuania (granulometric composition: fraction $1-2 \mathrm{~mm}-2.1 \%, 0.5-1 \mathrm{~mm}-7.9 \%, 0.25-0.5 \mathrm{~mm}-$ $34.5 \%, 0.125-0.25 \mathrm{~mm}-45.5 \%, 0.063-0.125 \mathrm{~mm}-$ $7.6 \%,<0.063 \mathrm{~mm}-2.4 \%$, corresponding to the standard LST EN 13139:2013.

Portland cement CEM II/A-L $42.5 \mathrm{~N}$ came from the Joint Stock Company Akmenès Cementas oeprating in Naujoji Akmene, Lithuania. It corresponds to the requirements of the standard LST EN 197-1:2011 and has the following mineral composition (in \%): $\mathrm{C}_{3} \mathrm{~S}-51.11$; $\mathrm{C}_{2} \mathrm{~S}-25.70 ; \mathrm{C}_{3} \mathrm{~A}-3.06 ; \mathrm{C}_{4} \mathrm{AF}-14.47$. The specific surface of Portland cement amounts to $4200 \mathrm{~cm}^{2} / \mathrm{g}, \mathrm{t}_{\mathrm{n}}-$ $330 \mathrm{~min}, \mathrm{t}_{\mathrm{k}}-375 \mathrm{~min}$.

Milled lime CL 90-Q was taken from the Joint Stock Company Naujasis Kalcitas established in Naujoji Akmene, Lithuania. It corresponds to requirements of the standard LST EN 459-2:2010 with $\mathrm{CaO}$ amounting to $85.2 \%$ and reactivity expressed by time $t_{u}$ of $3 \mathrm{~min}$, and temperature $\mathrm{T}_{\mathrm{u}}$ of $61.3^{\circ} \mathrm{C}$.

Special additives were used for improvement of properties: water retaining additive Bermocoll ML 31 produced by Akzo Nobel N. V. oeprating in Amsterdam, the Netherlands (white coloured powder, $\mathrm{pH} \sim 6.5$ of $5 \%$ water solution); levelling and plasticizing additive Loxanol K 12 P produced by Cognis from Monheim, Germany (white-coloured powder, $\mathrm{pH} \sim 9.8$ of $5 \%$ water solution). Additionally, the air entraining additive Ufapore TCO produced by Unger Fabrikker AS operating in Fredrikstad, Norway (white-coloured powder, $\mathrm{pH} \sim 8$ of $5 \%$ wa- ter solution, content of active material amounting to $94 \%$ ) was used to ensure high-quality adhesion of foam polystyrene crumbs and granules to the plaster matrix.

EPSC (bulk density $14 \mathrm{~kg} / \mathrm{m}^{3}$ from the Joint Stock Company Virginijus ir Ko established in Plungè, Lithuania; EPS (bulk density $14 \mathrm{~kg} / \mathrm{m}^{3}$ ) and NEOPOR (bulk density $21 \mathrm{~kg} / \mathrm{m}^{3}$ ) from the Joint Stock Company Baltijos Polistirenas located in Garliava, Lithuania were used as lightweight aggregates. All lightweight aggregates were sized $\leq 2 \mathrm{~mm}$.

The chemical composition of aggregates and binding materials is provided in Table 1.

Table 1. Chemical composition of raw materials

\begin{tabular}{c|c|c|c}
\hline \multirow{2}{*}{ Composition } & \multicolumn{3}{|c}{ Raw materials (\%) } \\
\cline { 2 - 4 } & Portland cement & Lime & Sand \\
\hline $\mathrm{SiO}_{2}$ & 22.41 & 4.04 & 90.40 \\
\hline $\mathrm{Al}_{2} \mathrm{O}_{3}$ & 4.20 & 2.22 & 4.02 \\
\hline $\mathrm{Fe}_{2} \mathrm{O}_{3}$ & 4.76 & 0.87 & 0.65 \\
\hline $\mathrm{TiO}_{2}$ & - & - & - \\
\hline $\mathrm{CaO}$ & 63.0 & 89.23 & 2.05 \\
\hline $\mathrm{MgO}$ & 2.5 & 2.37 & 0.49 \\
\hline $\mathrm{MnO}$ & - & - & - \\
\hline $\mathrm{K}_{2} \mathrm{O}+\mathrm{Na}{ }_{2} \mathrm{O}$ & - & 0.36 & 1.34 \\
\hline $\mathrm{SO}_{3}$ & 1.65 & - & - \\
\hline $\mathrm{LOI}_{0} \%$ & 1.33 & 0.86 & 1.02 \\
\hline
\end{tabular}

As provided in Table 2, the composition of mixes was selected based on references (Sinica et al. 2005; LST EN 998-1:2010; Sezemanas et al. 2013). Before dry mixes were prepared, lime was slaked by isothermal treatment for $0.5 \mathrm{~h}$ in the laboratory autoclave with the capacity of 100 litres (saturated water vapour pressure of $0.4 \mathrm{MPa}$ ).

Once slaked, lime was allowed to cool down to room temperature. All dry components - cement, lime and sand - and water retaining, levelling and plasticizing additives were mixed dry for $10 \mathrm{~min}$ in the mixer Bear Varimixer produced by $A / S$ Wodschow \& Co operating in Broendby, Denmark at a shaft speed of $60 \mathrm{rpm}$. Then, water, lightweight aggregate and air were added and

Table 2. Compositions of plaster forming mixes

\begin{tabular}{|c|c|c|c|c|c|c|c|c|c|}
\hline \multirow{2}{*}{$\begin{array}{l}\text { Plas- } \\
\text { ter }\end{array}$} & \multicolumn{3}{|c|}{ In mass $(\%)$} & \multicolumn{3}{|c|}{ Additives from Portland cement mass (\%) } & \multicolumn{3}{|c|}{$\begin{array}{l}\text { Volume of lightweight aggregates } \\
\text { (1 per } 1 \mathrm{~kg} \text { of dry mix) }\end{array}$} \\
\hline & $\begin{array}{c}\text { Portland } \\
\text { cement }\end{array}$ & Lime & Sand & $\begin{array}{l}\text { Water } \\
\text { retaining }\end{array}$ & $\begin{array}{l}\text { Leveling and } \\
\text { plasticizing }\end{array}$ & Air entraining & EPSC & EPS & NEOPOR \\
\hline $\mathrm{T}-1$ & 10 & 4 & 86 & 0.04 & 0.015 & 0.02 & - & - & - \\
\hline $\mathrm{T}-2$ & 10 & 4 & 86 & 0.04 & 0.015 & 0.02 & 1.25 & - & - \\
\hline $\mathrm{T}-3$ & 10 & 4 & 86 & 0.04 & 0.015 & 0.02 & 1.50 & - & - \\
\hline $\mathrm{T}-4$ & 10 & 4 & 86 & 0.04 & 0.015 & 0.02 & 1.75 & - & - \\
\hline $\mathrm{T}-5$ & 10 & 4 & 86 & 0.04 & 0.015 & 0.02 & - & 1.25 & - \\
\hline T-6 & 10 & 4 & 86 & 0.04 & 0.015 & 0.02 & - & 1.50 & - \\
\hline $\mathrm{T}-7$ & 10 & 4 & 86 & 0.04 & 0.015 & 0.02 & - & 1.75 & - \\
\hline $\mathrm{T}-8$ & 10 & 4 & 86 & 0.04 & 0.015 & 0.02 & - & - & 1.25 \\
\hline $\mathrm{T}-9$ & 10 & 4 & 86 & 0.04 & 0.015 & 0.02 & - & - & 1.50 \\
\hline $\mathrm{T}-10$ & 10 & 4 & 86 & 0.04 & 0.015 & 0.02 & - & - & 1.75 \\
\hline
\end{tabular}


mixed for additional $5 \mathrm{~min}$ at the same speed. In each case, the amount of water was taken considering the flow ability of plaster grout determined using the flow table and until the diameter of a sample reached $160 \pm 5 \mathrm{~mm}$ according to the standard LST EN 1015-3:2002.

The produced plaster mix was used to fill: cubes sized $70 \times 70 \times 70 \mathrm{~mm}$ - to determine the compressive strength; plates sized $300 \times 300 \times 50 \mathrm{~mm}-$ to determine the thermal conductivity coefficient; and plates $160 \mathrm{~mm}$ in diameter and $30 \mathrm{~mm}$ thick - to determine the relative vapour resistance. Plaster grout was kept for 2 days in moulds covered with polyethylene film; then, hardened samples were de-moulded and kept for 26 days in the climatic chamber at a temperature of $20 \pm 3{ }^{\circ} \mathrm{C}$ and relative air humidity of $95 \pm 5 \%$.

The density and compressive strength of hardened plasters were determined according to standards LST EN 1015-10:2004 and LST EN 1015-11:2004.

The compressive strength was determined after 28 days, with the help of the press $\mathrm{H} 200 \mathrm{kU}$ produced by Tinius Olsen Ltd from Salfords, England at a load speed of $200 \mathrm{~N} / \mathrm{s}$ and load measurement accuracy of $\pm 0.5 \%$ of applied load from $0.2 \%$ to $100 \%$ of the capacity.

The thermal conductivity coefficient of plaster samples was determined according to the standard LST EN 12664:2002 using $\lambda$-meter EP500 produced by Lambda-Meßtechnik GmbH established in Dresden, Germany. After the first measurement, aiming to estimate the impact of the coat on the thermal conductivity coefficient of plaster, the plaster samples were coated with a layer $(0.5 \mathrm{~mm})$ of decorative paint Super Therm produced by Superior Products International II Inc operating in Shawnee, USA, and dried at a room temperature. Then, the samples were repeatedly measured for the thermal conductivity coefficient.

The relative vapour resistance was determined according to the standard LST EN 1015-19:2001. The climatic conditions of temperature mode 23-50/95 (i.e. environmental temperature $-23{ }^{\circ} \mathrm{C}$, relative air humidity over the sample $-50 \%$, relative air humidity under the sample $-95 \%$ ).

Aiming to determine the force of adhesion between hardened plaster and other surfaces, 3 manufactured blocks were selected for tests: a ceramic block (Keraporas, Joint Stock Company Roku Keramika, Kaunas, Lithuania), a silicate block (Siliblokas, Joint Stock Company Matuizu plytine, Varena district, Lithuania) and an autoclaved aerated concrete block (Poritas, Joint Stock Company Matuzu Duju Silikatas, Varèna District, Lithuania). A $10 \mathrm{~mm}$ layer of freshly prepared plaster was sprayed on moistened lateral surface of the block and puttied. After 2 hours, the plastered surface of blocks was covered with polyethylene film and the samples were kept in such state for 28 days at a room temperature.

The force of adhesion to the surface of aforementioned blocks was measured using 58-C0215/T produced by Controls S.r.L. located in Cernusco s/N, Italy according to the standard method established in LST EN 101512:2004.
The character of disintegration in plaster samples of diameter $50 \mathrm{~mm}$, torn off surface of blocks, was estimated visually and fixed by digital camera PC1057, Canon Inc., Tokyo, Japan. For investigation of microstructure of samples, the zones of interest were selected (contact zones between aggregates and matrix, between paint film and plaster surface) and scanned by scanner SCX-4200, Samsung Group, Guangdong, China and observed by stereo microscope K-400L, Motic Group Co. LTD, Xiamen, China with magnification up to 100 times.

Mathematical-statistical methods were used to process experimental data and evaluate their reliability. Such methods provide a fairly accurate assessment of density, compressive strength, thermal conductivity and relative vapour resistance values. In addition, they allow for evaluation of the scattering of found values and determination of the distribution functions and parameters. The calculations were carried out using the mathematical-statistical program Statistica (Ayvazyan 1968; Williams 1959; STATSOFT 2014).

\section{Results and discussion}

The impact of lightweight aggregates on density of plaster is shown in Figure 1.

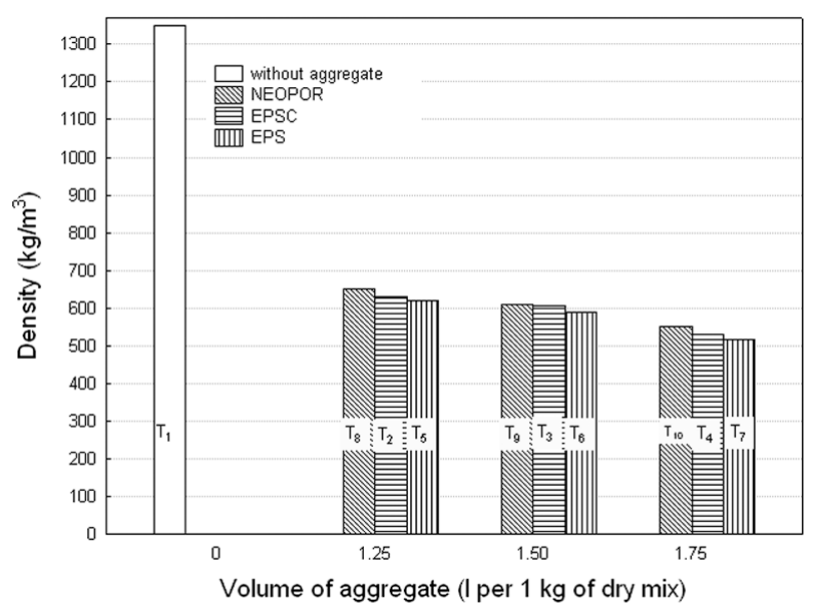

Fig. 1. Impact of aggregate type and content on density of plaster

The results of investigations show that all aggregates reduce the density of plaster proportionally, depending on their content (from $1350 \mathrm{~kg} / \mathrm{m}^{3}$ in the composition T-1, to $515 \mathrm{~kg} / \mathrm{m}^{3}$ in the composition T-7). Samples with NEOPOR had a slightly higher density, which is understandable as the mass of NEOPOR is higher by almost $30 \%$ than that of EPSC or EPS. The compressive strength of plaster samples changes in a similar way (Fig. 2).

If the strength of a sample without lightweight aggregates (T-1) reaches 1.4 MPa, then, together with the increase in lightweight aggregate content, the compressive strength decreases proportionally from $0.4 \mathrm{MPa}$ (when the content of aggregate is from 1.251 (per $1 \mathrm{~kg}$ of dry mix) to $0.3 \mathrm{MPa}(1.5 \mathrm{l} / 1 \mathrm{~kg})$ and to $0.2 \mathrm{MPa}(1.75 \mathrm{l} / 1 \mathrm{~kg})$. In all cases, the compressive strength of plaster with NEOPOR is 
higher (by 19.5-34.5\%, columns T-4, T-7 and T-10) than that of plaster with EPSC (columns T-2, T-5, T-8) and plasters with EPS (by 8.9-25\%, columns T-3, T-6 and T-9).

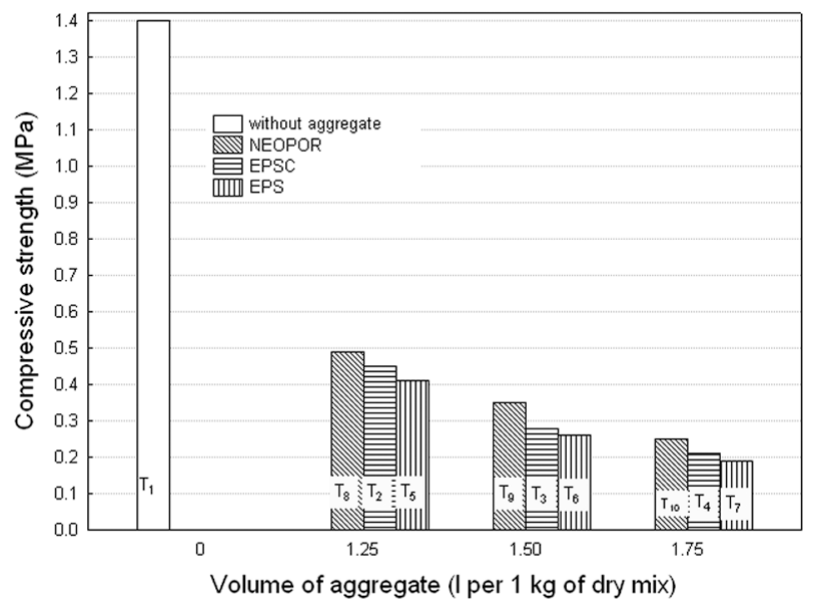

Fig. 2. Impact of aggregate type and content on the compressive strength of plaster

The values of thermal conductivity coefficient of plaster samples are provided in Figure 3.

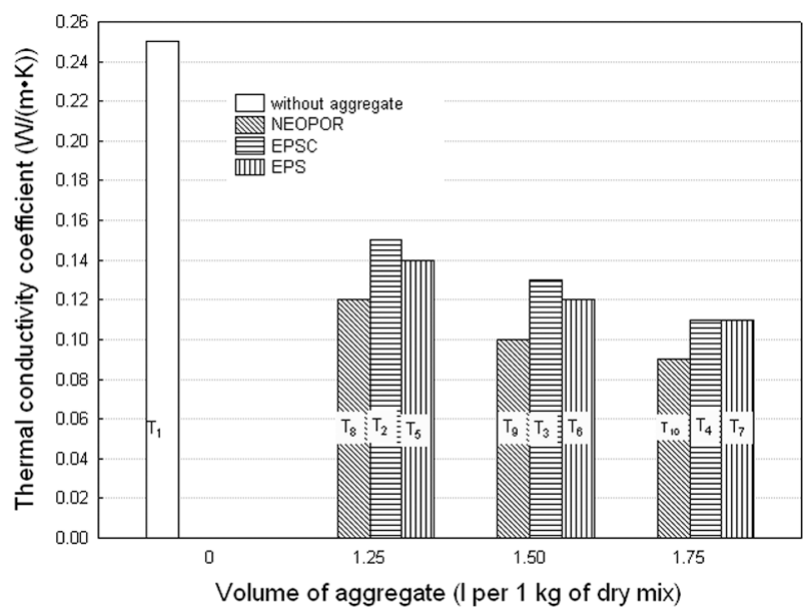

Fig. 3. Impact of aggregate type and content on the thermal conductivity coefficient of plaster

The data of Figure 3 show that lightweight aggregates, subject to their content in plaster, can decrease the value of thermal conductivity coefficient by $2-2.5$ times, from $0.25 \mathrm{~W} /(\mathrm{m} \cdot \mathrm{K})$ (Fig. 3, column $\mathrm{T}-1$ ) to 0.09 $0.12 \mathrm{~W} /(\mathrm{m} \cdot \mathrm{K})$ (Fig. 3, columns $\mathrm{T}-2$ and $\mathrm{T}-10)$. As expected, in all cases (Fig. 3, columns T-4, T-7, T-10), the lowest thermal conductivity coefficient belongs to the plaster with NEOPOR, which contains graphite as an additive and, thus, ensures better thermal properties of these aggregates and respective plaster samples (Fig. 3, columns T-4, T-7, T-10). In comparison with these samples, the thermal conductivity coefficient in plasters with EPSC are higher by $21.4-26.6 \%$ (Fig. 3, columns T-2, $\mathrm{T}-5$ and T-8) versus plasters with EPS.
Among plasters with EPSC, plasters with EPS (Fig. 3, columns T-3, T-5 and T-8) demonstrate somewhat lower (by 13.3-16.6\%) values of thermal conductivity coefficient.

In terms of EPS, this can be explained by the coating of the surface with partially melted polystyrene film, under which the expanded multi-porous carcass of material is located. Meanwhile in case of EPSC, the envelope is injured during mechanical crushing, therefore, the stream of heat penetrates easier through them.

Samples of plaster were also coated with decorative paint. The measurements of the thermal conductivity coefficient showed that decorative paint does not impact on the properties of thermo-insulating plasters; however, it adheres to the plaster surface very well and may be used as a decorative finish.

Investigations of the impact of lightweight aggregate additives on relative vapour resistance established that the plaster with EPSC has the best water vapour permeability (Fig. 4, Column T-2).

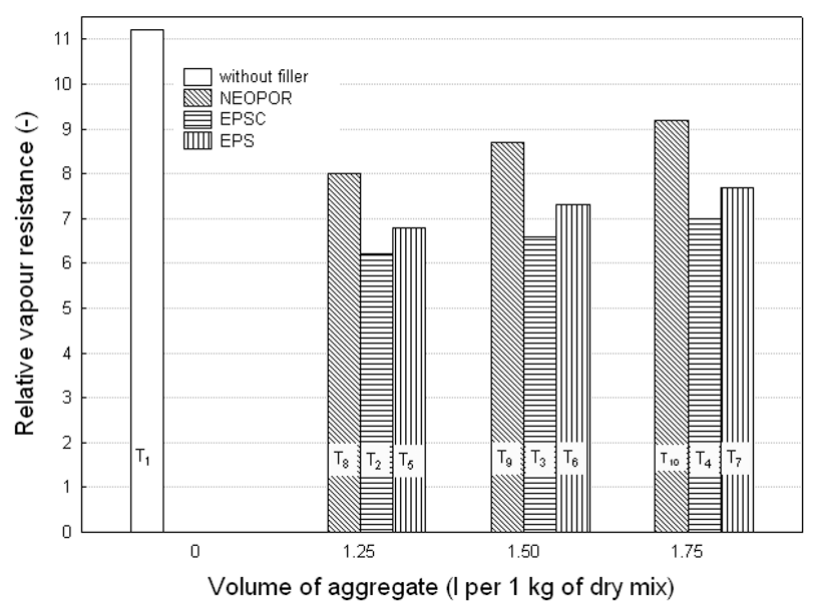

Fig. 4. Impact of aggregate type and content on relative vapour resistance of plaster

The relative vapour resistance (6.2) is even lower by $44.6 \%$ than that of plaster without lightweight additive (Column T-1); 8.8\% lower than the plaster with EPS (Column T-3); and 22.5\% lower than that of plaster with NEOPOR (Column T-4). This can be explained by the fact that water vapour passes easily through injured ESPC areas; meanwhile, water vapour permeability falls when water vapour goes through spherical coat-containing granules.

According to the standard LST EN 1015-11:2004, the compressive strength of thermo-insulating plaster should correspond to class CS-1, i.e. it should be no less than $0.4 \mathrm{MPa}$.

The results of performed investigations showed that the compressive strength of thermo-insulating plaster meets the standard requirements only when the content of lightweight aggregate in plaster reaches 1.251 per $1 \mathrm{~kg}$ of dry mix of plaster (Fig. 2). Since the compressive strength of all modified plasters was similar $\left(R_{c}=0.4 \mathrm{MPa}\right)$, the adhesion force of thermo-insulating plasters was determined only for samples with EPSC. 
Considering the adhesion of plaster to coated surfaces, we should, once again, pay attention to the structure of plaster. Figure 5 suggests that EPSC occupy a large surface area, which means poor adhesion of such aggregates with the coated surface, since the bond is ensured only by plaster matrix.

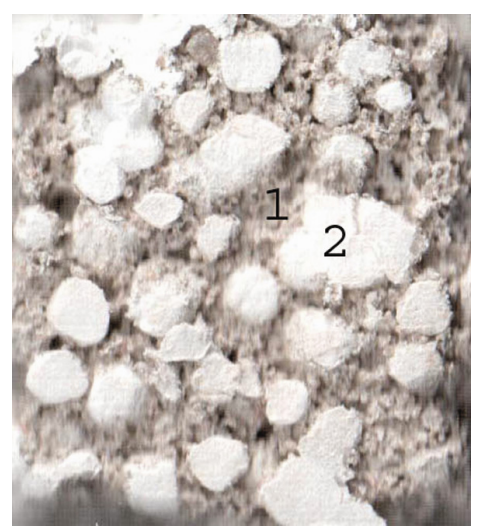

Fig. 5. Surface of plaster with EPSC: 1 - matrix; 2 - aggregate

The character of adhesion between a plaster and a coated surface shows that in the presence of an additional contact area, into which plaster penetrates (additional small grooves in ceramic blocks (Fig. 6a), open pores in autoclaved aerated concrete (Fig. 6b), the forces of adhesion is sufficient and disintegration takes place through the layer of plaster, fully or partially (Fig. 7a, b).

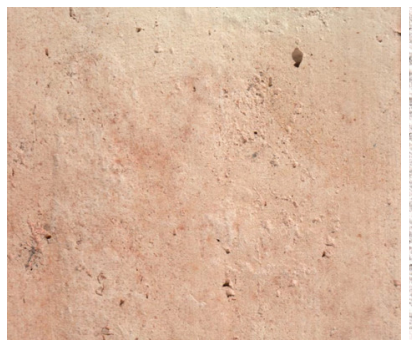

a

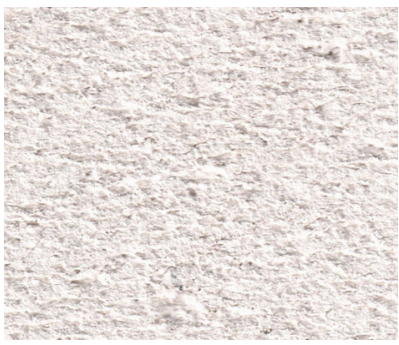

$\mathrm{b}$

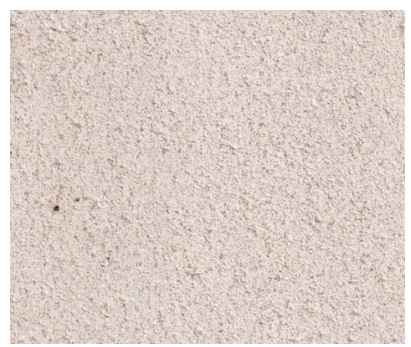

C

Fig. 6. Different surfaces of building blocks: a - ceramic; $\mathrm{b}$ - autoclaved aerated concrete; $\mathrm{c}$ - silicate

Meanwhile, at a relatively even silicate surface (Fig. 6c), the plaster adheres only to the plaster matrix and the surface of adhesion does not ensure a good bond (Fig. 7c), although coated surfaces are almost of the same smoothness (Fig. 6a and c). The values regarding the adhesion force of plaster to considered surfaces are provided in Table 3.

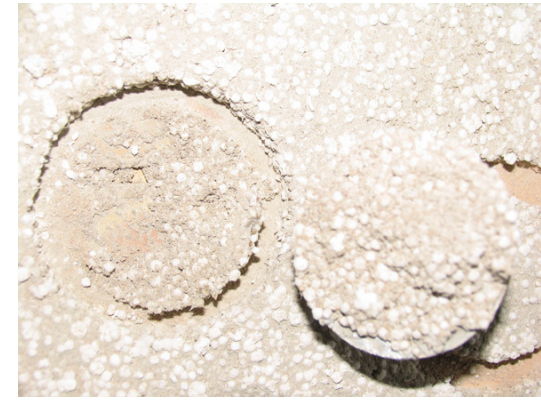

a

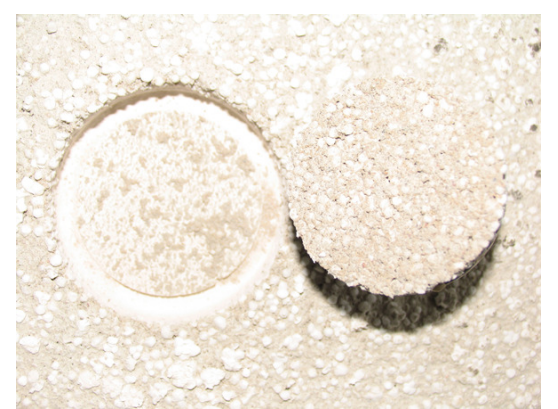

$\mathrm{b}$

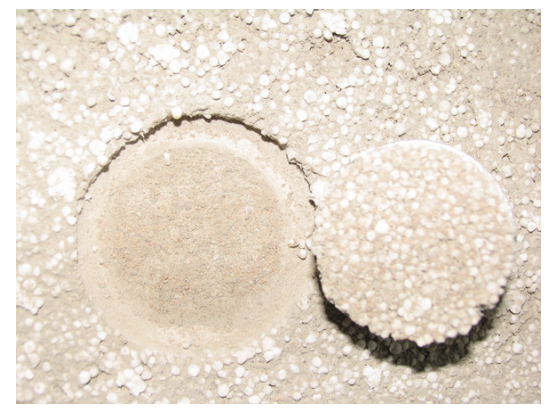

Fig. 7. Character of disintegration of plasters on different surfaces of building blocks after an experiment: a - ceramic; $\mathrm{b}$ - autoclaved aerated concrete; $\mathrm{c}$ - silicate

Table 3. Force of adhesion between plaster and different surfaces of building blocks

\begin{tabular}{c|c|l}
\hline $\begin{array}{c}\text { Coated } \\
\text { surface }\end{array}$ & $\begin{array}{c}\text { Force of adhesion } \\
\text { (MPa) }\end{array}$ & \multicolumn{1}{|c}{$\begin{array}{c}\text { Character } \\
\text { of disintegration }\end{array}$} \\
\hline Ceramic block & 0.21 & $\begin{array}{l}\text { Trough layer of } \\
\text { plaster }\end{array}$ \\
\hline AAC block & 0.15 & $\begin{array}{l}\text { Trough contact area } \\
(4 / 5 \text { parts }) \\
\text { Trough layer of } \\
\text { plaster }(1 / 5 \text { part })\end{array}$ \\
\hline Silicate block & 0.05 & Trough contact area \\
\hline
\end{tabular}

According to Table 3, the data are closely related to structure of plaster and structures of coated product surfaces.

The structure of plaster without lightweight aggregates consists of modified matrix formed of binding material components (cement and lime) modified by water retaining and levelling, plasticizing additives and aggregate - sand (Fig. 8 ). 


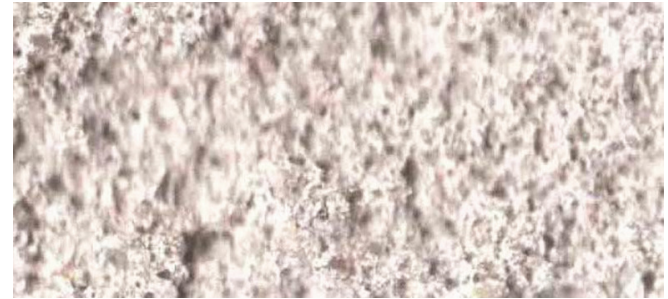

Fig. 8. Macro structure of plaster without lightweight aggregate

The density $\left(1350 \mathrm{~kg} / \mathrm{m}^{3}\right)$ suggests that a structure contains voids, which reduces the density of plaster. In Figure 9, voids are clearly visible. The value of compressive strength $(1.4 \mathrm{MPa})$ is decided by the carcass formed of sand grains mutually linked by the cementing matrix.

With addition of EPSC to plaster, the structure of plaster gets changed: the content of matrix decreases and that of aggregate increases. Keeping in mind that EPSC have a small compressive strength, a conclusion can be made regarding the formation of a porous structure where EPSC partly replace large pores (Fig. 6). Consequently, a thermo-insulating plaster is received, the strength of which is determined by strength of inter-pore walls, i.e. thickness of walls and strength of the matrix. The air entraining additive forms additional voids in the interpore walls and those voids influence the properties of plaster: for instance, reduce the thermal conductivity and, simultaneously, the density and compressive strength.

Painted plasters (without lightweight additives and with EPSC) provide a sufficiently good bond between contacting surfaces. The layer of paint fills all gaps in the coated surface and adheres well to it (Fig. 9a and b).

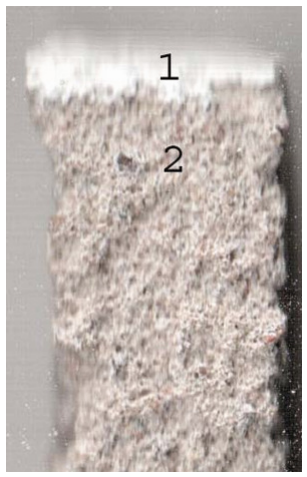

a

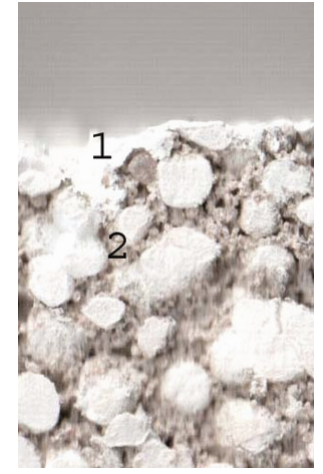

b
Fig. 9. Plasters with painted surface: a - plaster without lightweight additives, $b$ - plaster with EPSC. 1 - decorative paint, 2 - plaster

To establish the regression dependence of compressive strength, thermal conductivity coefficient and relative vapour resistance on density of plasters, the dependence of density on the content of lightweight aggregate was provided additionally (Fig. 10).

The analysis of experimental data showed that the density of thermo-insulating plasters depends on the type of lightweight aggregate and can be expressed by the following equations (Table 4).

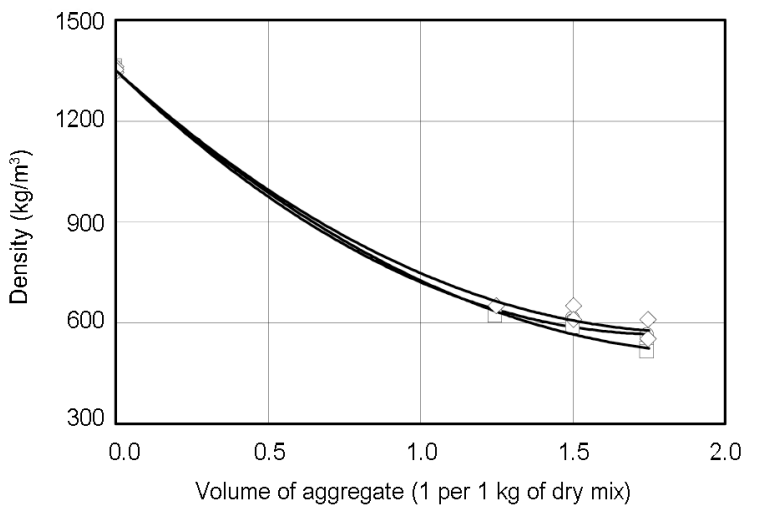

Fig. 10. Dependence of type of lightweight aggregates on density of thermo-insulating plaster: ○ - EPSC; $\square-$ EPS; $\diamond-$ NEOPOR

Table 4. Regression analysis of density (in $\mathrm{kg} / \mathrm{m}^{3}$ ) of thermoinsulating plasters

\begin{tabular}{|c|c|c|c|}
\hline Aggregate & $\begin{array}{c}\text { Regression } \\
\text { equation }\end{array}$ & 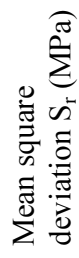 & 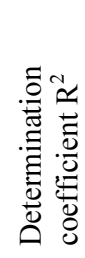 \\
\hline EPSC & $\rho=1351.2-871.3 \cdot F+241.8 \cdot F^{2}$ & 12.6 & 0.998 \\
\hline EPS & $\rho=1351.0-827.5 \cdot F+203.2 \cdot F^{2}$ & 16.8 & 0.998 \\
\hline NEOPOR & $\rho=1351.2-802.8 \cdot F+199.3 \cdot F^{2}$ & 11.1 & 0.999 \\
\hline
\end{tabular}

The performed analysis showed that the variation of density values of thermo-insulating plasters is $\sim 99.8 \%$, subject to type of lightweight aggregate. It may be seen from the diagram that the intense decrease in density is in the interval from 1358 (plaster without lightweight aggregates) to $600 \mathrm{~kg} / \mathrm{m}^{3}$ (plaster with different types of lightweight aggregates). Upon evaluation of impact of different type of lightweight aggregates on density of thermo-insulating plasters, one can draw a conclusion that their influence is identical.

Basing on the results shown in Figure 11, a review was carried out on a possibility to predict and to evaluate the compressive strength of thermo-insulating plaster,

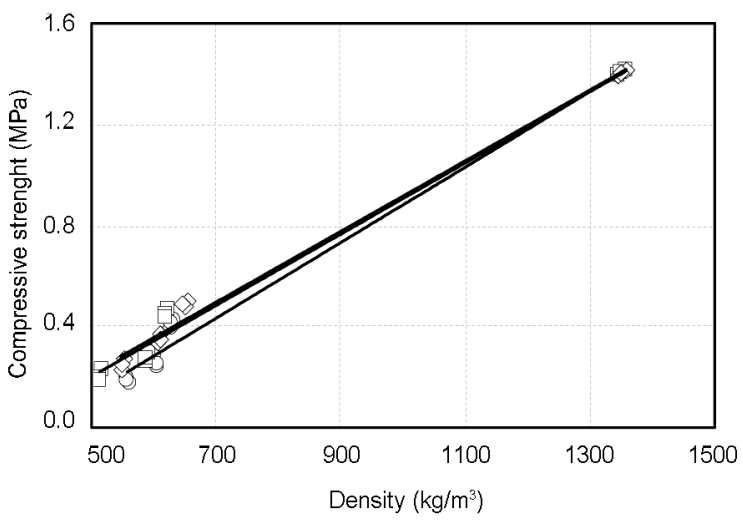

Fig. 11. Dependence of density on compressive strength of thermo-insulating plaster: $\odot-$ EPSC; $\square-\mathrm{EPS} ; \diamond-\mathrm{NEOPOR}$ 
subject to its density. In this case, the compressive strength is approximated by the following equations (Table 5). The analysis showed that the compressive strength decreases linearly pro rata density of plasters, and that the influence of density on compressive strength is of $\sim 99.0 \%$. Subject to content of different types of lightweight aggregates, at the same density, e.g. $630 \mathrm{~kg} / \mathrm{m}^{3}$, the difference in compressive strength can make up to $22 \%$.

Table 5. Regression analysis of compressive strength (in MPa) of thermo-insulating plasters

\begin{tabular}{|c|c|c|c|}
\hline Aggregate & $\begin{array}{l}\text { Regression } \\
\text { equation }\end{array}$ & 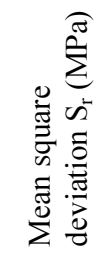 & 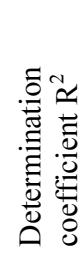 \\
\hline EPSC & $R_{c}=0.00149 \cdot \rho-0.6126$ & 0.0535 & 0.990 \\
\hline EPS & $R_{c}=0.00141 \cdot \rho-0.5029$ & 0.0555 & 0.989 \\
\hline NEOPOR & $R_{c}=0.00140 \cdot \rho-0.4829$ & 0.0426 & 0.993 \\
\hline
\end{tabular}

Figure 12 depicts the dependence of density of thermo-insulating plaster on experimental values of thermal conductivity coefficient, which can be described by the following regression equations (Table 6).

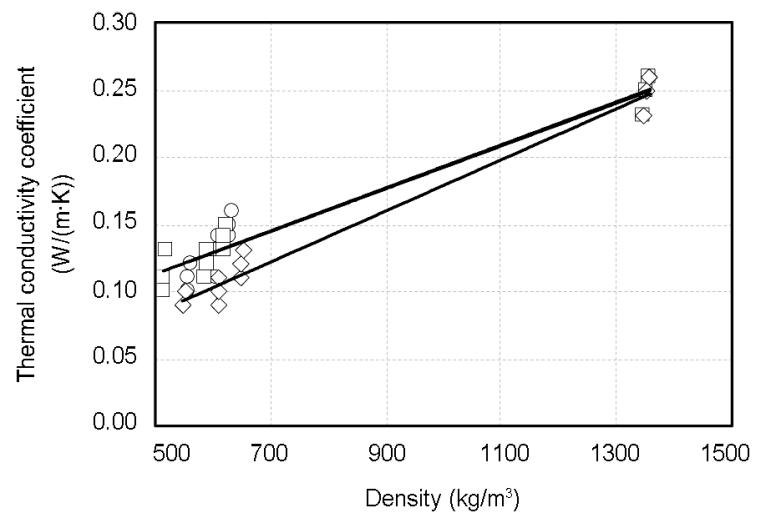

Fig. 12. Dependence of density of thermo-insulating plaster on thermal conductivity coefficient: $\bigcirc-$ EPSC; $\square-$ EPS; $\diamond-$ NEOPOR

Table 6. Regression analysis of thermal conductivity coefficient (in $\mathrm{W} /(\mathrm{m} \cdot \mathrm{K})$ ) of thermo-insulating plasters

\begin{tabular}{|c|c|c|c|}
\hline Aggregate & $\begin{array}{l}\text { Regression } \\
\text { equation }\end{array}$ & 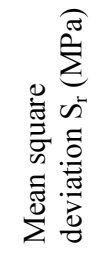 & 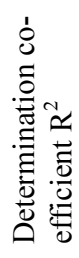 \\
\hline EPSC & $\lambda_{10^{\circ} \mathrm{C}}=0.00016 \cdot \rho+0.03339$ & 0.0159 & 0.927 \\
\hline EPS & $\lambda_{10^{\circ} \mathrm{C}}=0.00016 \cdot \rho+0.03312$ & 0.0127 & 0.955 \\
\hline NEOPOR & $\lambda_{10^{\circ} \mathrm{C}}=0.00019 \cdot \rho-0.01106$ & 0.0103 & 0.977 \\
\hline
\end{tabular}

The experimental results show that thermal conductivity coefficient decreases proportionally together with a decrease in density of plaster, and that the influence of density, subject to type of lightweight aggregates, on thermal conductivity coefficient amounts to $\sim 95.0 \%$. At the same density, for instance, $630 \mathrm{~kg} / \mathrm{m}^{3}$, subject to the content of lightweight aggregates, the difference in thermal conductivity coefficient can make up to $24 \%$.

Figure 13 illustrates the dependence of density of thermo-insulating plaster on experimental values of relative vapour resistance, which can be described by the following regression equations (Table 7).

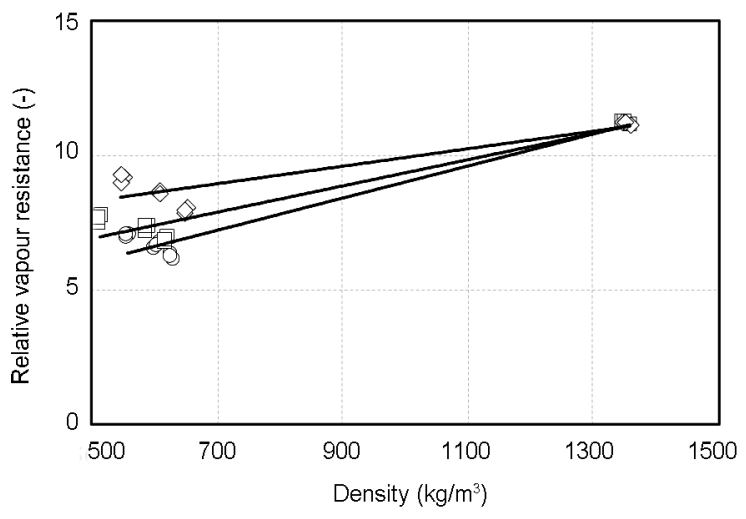

Fig. 13. Dependence of density of thermo-insulating plaster on relative vapour resistance. $\bigcirc-$ EPSC; $\square-\mathrm{EPS} ; \diamond-\mathrm{NEOPOR}$

Table 7. Regression analysis of relative vapour resistance of thermo-insulating plasters

\begin{tabular}{|c|c|c|c|}
\hline Aggregate & $\begin{array}{c}\text { Regression } \\
\text { equation }\end{array}$ & 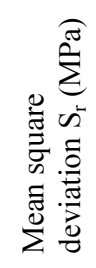 & 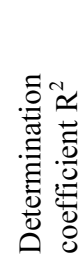 \\
\hline EPSC & $\mu=0.0598 \cdot \rho+3.032$ & 0.467 & 0.954 \\
\hline EPS & $\mu=0.0489 \cdot \rho+4.464$ & 0.589 & 0.916 \\
\hline NEOPOR & $\mu=0.00325 \cdot \rho+6.670$ & 0.589 & 0.795 \\
\hline
\end{tabular}

The experimental results show that relative vapour resistance decreases proportionally together with a decrease in density of plaster, and that the influence of density, subject to a type of lightweight aggregates, on relative vapour resistance varies from 80 to $\sim 95.0 \%$. At the same density, for instance, $630 \mathrm{~kg} / \mathrm{m}^{3}$, subject to the content of lightweight aggregates, the difference in relative vapour resistance can make up to $28 \%$.

The comparison of experimental results of thermoinsulating plasters enables to state that the physicalmechanical properties, subject to density of plaster (and density depends on the type of lightweight aggregates), can rather considerably differ. Therefore, a great attention should be paid to selection of compositions for such plasters in order to get the optimal physical-mechanical properties. 


\section{Conclusions}

The content of lightweight aggregate - foam expanded polystyrene package crumbs (EPSC) - added to the thermo-insulating plaster in as high as $1.25 \mathrm{l} / \mathrm{kg}$ of dry mix of plaster ensures the strength of class CS-1, i.e. the compressive strength of $0.4 \mathrm{MPa}$ for the plaster containing $10 \%$ of Portland cement only.

It was established that EPSC in the abovementioned quantity $(1.25 \mathrm{l} / \mathrm{kg}$ of dry mix of plaster) improves the properties of plaster in the following way:

- the thermal conductivity coefficient - from 0.25 to

$0.13 \mathrm{~W} /(\mathrm{m} \cdot \mathrm{K})$;

- the relative vapour resistance - from 11.2 to 6.2 ;

- the density - from 1350 to $620 \mathrm{~kg} / \mathrm{m}^{3}$.

It was established that the impact of different types of lightweight aggregates on properties of plaster is identical.

The regression equations are provided for their possible use in prediction of modified plaster properties such as density, compressive strength, thermal conductivity coefficient, relative vapour resistance, subject to the content of lightweight aggregate.

\section{Acknowledgement}

This work was supported by the Research Council of Lithuania (contract No ATE-07/2012)

\section{References}

Ayvazyan, S. A. 1968. Statisticheskoye issledovaniye zavisimostey: (primeneniye metodov korrelya-tsionnogo i regressionnogo analizov $k$ obrabotke rezultatov eksperimenta) [Statistical analysis of dependencies: (application of correlation and regression analyses and processing of experimental results)]. Moskva: Metallurgiya. $228 \mathrm{~s}$.

Davraz, M.; Gunduz, L.; Baspinar, E. 2011. Lightweight aggregated foam plaster for thermal insulation in buildings, Journal of Engineering Science and Design 1(3): 150155.

Demirboga, K.; Kan, A. 2012. Thermal conductivity and shrinkage properties of modified waste polystyrene aggregate concretes, Construction and Building Materials 35: 730-734.

http://dx.doi.org/10.1016/j.conbuildmat.2012.04.105

Ducman, V.; Mirtič, B. 2011. Lightweight aggregate processed from waste materials, in Wythers, M. C. (Ed.). Advances in Materials Science Research. New York: Nova Science Publishers, Inc., 4: 307-323.

Gutierrez-Gonzalez, S.; Gadea J.; Rodrigue, A.; Junco, C.; Calderon, V. 2012. Lightweight plaster materials enhanced thermal properties made with polyurethane foam wastes, Construction and Building Materials 28(1): 653658. http://dx.doi.org/10.1016/j.conbuildmat.2011.10.055

Herrero, S.; Mayor P.; Hernandez-Olivares, I. 2013. Influence of proportion and particle size gradation of rubber from end-of-life tires on mechanical, thermal and acoustic properties of plaster-rubber mortars, Materials \& Design 47: 633-642. http://dx.doi.org/10.1016/j.matdes.2012.12.063

Koksal, F.; Gencel, O.; Brostow, W.; Hagg Lobland, H. E. 2012. Effect of high temperature on mechanical and physical properties of lightweight cement based refractory in- cluding expanded vermiculite, Materials Research Innovations 16(1): 7-13.

http://dx.doi.org/10.1179/1433075X11Y.0000000020

Limbachiya, M.; Meddah, M. S.; Fotiadou, S. 2012. Performance of granulated foam glass concrete, Construction and Building materials 28(1): 759-768.

http://dx.doi.org/10.1016/j.conbuildmat.2011.10.052

LST EN 1015-10:2004 Müro skiedinio bandymo metodai. 10 dalis. Sukietejjusio sauso skiedinio tūrinio tankio nustatymas [Methods of test for mortar for masonry - Part 10: Determination of dry bulk density of hardened mortar]. Lietuvos standartizacijos departamentas [Lithuanian Standards Board], 2004. 6 p.

LST EN 1015-11:2004 Mūro skiedinio bandymo metodai. 11 dalis. Sukietèjusio skiedinio stiprio lenkiant ir gniuždant nustatymas [Methods of test for mortar for masonry - Part 11: Determination of flexural and compressive strength of hardened mortar]. Lietuvos standartizacijos departamentas [Lithuanian Standards Board], 2004. 11 p.

LST EN 1015-12:2004 Mūro skiedinio bandymo metodai. 12 dalis Sukietejusiu tinko skiediniu sukibimo su pagrindu stiprio nustatymas [Methods of test for mortar for masonry - part 18: determination of adhesive strength of hardened rendering and plastering mortars on substrates]. Lietuvos standartizacijos departamentas [Lithuanian Standards Board], 2004. 9 p.

LST EN 1015-19:2001 Mūro skiedinio bandymo metodai. 19 dalis. Tinko skiediniu laidumo vandens garams nustatymas [Methods of test for mortar for masonry - Part 19: Determination of water vapour permeability of hardened rendering and plastering mortars] Lietuvos standartizacijos departamenas [Lithuanian Standards Board], 2001. $8 \mathrm{p}$.

LST EN 1015-3:2002 Mūro skiedinio bandymo metodai. 3 dalis. Šviežio skiedinio konsistencijos nustatymas (sklidumo metodu) [Methods of test for mortar for masonry - Part 3: Determination of consistence of fresh mortar (by flow table)] Lietuvos standartizacijos departamentas [Lithuanian Standards Board], 2004. 9 p.

LST EN 12664:2002 Šiluminès statybiniu medžiagu ir gaminiu charakteristikos. Šluminès varžos nustatymas apsaugotos karštosios plokštès ir šilumos srauto matuoklio metodais. Vidutinès ir mažos šiluminès varžos sausi ir drègni gaminiai [Thermal performance of building materials and products - Determination of thermal resistance by means of guarded hot plate and heat flow meter methods - Dry and moist products of medium and low thermal resistance] Lietuvos standartizacijos departamentas [Lithuanian Standards Board], 2002. 67 p.

LST EN 13139:2013 Skiedinio užpildai [Aggregates for mortar]. Lietuvos standartizacijos departamentas [Lithuanian Standards Board], 2013. 40 p.

LST EN 197-1:2011 Cementas. 1 dalis. Iprastiniu cementu sudetis, techniniai reikalavimai ir atitikties kriterijai [Cement - Part 1: Composition, specifications and conformity criteria for common cements] Lietuvos standartizacijos departamentas [Lithuanian Standards Board], 2012. $34 \mathrm{p}$.

LST EN 459-2:2010 Statybinès kalkès. 2 dalis. Bandymo metodai [Building lime - Part 2: Test methods] Lietuvos standartizacijos departamentas [Lithuanian Standards Board], 2010. $64 \mathrm{p}$.

LST EN 998-1:2010 Techniniai mūro skiedinio reikalavimai. 1 dalis. Tinko skiedinys [Specification for mortar for masonry - Part 1: Rendering and plastering mortar] Lietuvos 
standartizacijos departamentas [Lithuanian Standards Board], 2012. $22 \mathrm{p}$.

Mikulskiy, V. G; Goriachkov, G. I.; Kozlov, V. V.; Kuprijanov, V. I.; Orentliher, L. P.; Rahimov, P. Z.; Sacharov, G. P.; Hrulev, V. M. 2007. Stroitelnyye materialy (Materialovedeniye. Tekhnologiya konstruktsionnykh materialov) [Building materials (Materials science. Technology of construction materials)]. Moskva: Izdatelstvo Assotsiatsii stroitelnykh vuzov. $520 \mathrm{~s}$.

Narayanan, N.; Ramamurthy, K. 2000. Structure and properties of aerated concrete: a review, Cement and Concrete Composites 22(5): 321-329. http://dx.doi.org/10.1016/S0958-9465(00)00016-0

Ramamurthy, K.; Narayanan, N. 2000. Factors influencing the density and compressive strength of aerated concrete, Magazine of Concrete Research 52(3): 163-168. http://dx.doi.org/10.1680/macr.2000.52.3.163

Ries, J. 2008. Structural lightweight aggregate and concrete, Structure June: 62-63.

Sari, A.; Karaipeikli, A. 2008. Preparation, thermal properties and thermal reliability of capric acid/expanded perlite composite for thermal energy storage, Materials Chemistry and Physics 109(2-3): 459-464. http://dx.doi.org/10.1016/j.matchemphys.2007.12.016

Sezemanas, G.; Sinica, M.; Zacharčenko, P.; Pivenj, N.; Mikulskis, D.; Kligys, M. 2013. Influence of zeolite additive on the properties of plaster used for external walls from autoclaved aerated concrete, Materials Science - Medžiagotyra 19(2): 222-229.
Sinica, M.; Laukaitis, A.; Sezeman, G. A.; Kligys, M. 2008. Operational properties of a heat-insulation composite with expanded polystyrene crumbs, Mechanics of Composite Materials 44(4): 415-424. http://dx.doi.org/10.1007/s11029-008-9033-x

Sinica, M.; Sezemanas, G. A.; Česnauskas, V. 2005. Orą itraukiančio priedo itaka tinko, skirto iš autoklavinio akytojo betono blokeliu sumūrytoms atitvaroms dengti, savybems [Influence of air absorbing additive on plaster layer properties designated to cover partitions built from autoclave porous concrete blocks], Chemical Technology - Chemine Technologija 4(38): 91-95.

STATSOFT. 2014. Electronic statistics textbook [online], [cited 10 January 2014]. Available from Internet: https://www.statsoft.com/Textbook

Topcu, I. B.; Isikdag, B. 2008. Effect of expanded perlite aggregate on the properties of light weight concrete, Journal of Materials Processing Technology 204(1-3): 34-38. http://dx.doi.org/10.1016/j.jmatprotec.2007.10.052

Ungkoon, Y.; Sittipunt, Ch.; Namprakai, P.; Jetipattaranat, W.; Kim, K. S.; Charinpanitkul, T. 2007. Analysis of microstructure and properties of autoclaved aerated concrete wall construction materials, Journal of Industrial and Engineering Chemistry 13(7): 1103-1108.

Williams E. J. 1959. Regression analysis. New York: John Wiley and Sons. 214 p.

Jurga ŠEPUTYTE்-JUCIKE். PhD student, Senior Engineer of Vilnius Gediminas Technical University Scientific Institute of Thermal Insulation (VGTU). MSc in Construction Technologies 2012. Research interests: lightweight concrete and insulating materials.

Georgij Arsenij SEZEMAN. Dr, Senior Scientific Officer of Vilnius Gediminas Technical University Scientific Institute of Thermal Insulation (VGTU). Doctor of Technological Sciences (chemical engineering), 2004. Publications: author and co-author of 55 scientific publications, 12 inventions and 4 patents. Research interests: lightweight concrete and insulating materials, technology and application of materials.

Marijonas SINICA. Dr, Senior Scientific Officer of Vilnius Gediminas Technical University Scientific Institute of Thermal Insulation (VGTU). Doctor of Technological Sciences (materials engineering), 2001. Publications: author and co-author of 1 monograph, 66 scientific publications, 39 inventions and 6 patents. Research interests: enclosures, cellular concrete, lightweight heat and fire insulating materials.

Modestas KLIGYS. Dr, Senior Scientific Officer of Vilnius Gediminas Technical University Scientific Institute of Thermal Insulation (VGTU). Doctor of Technological Sciences (materials engineering), 2009. Publications: author and co-author of 20 scientific publications and 2 patents. Research interests: cement-based composites, waste recycling and reuse, technology and application of building materials.

Saulius VAITKUS. Dr, Senior Scientific Officer of Vilnius Gediminas Technical University Scientific Institute of Thermal Insulation (VGTU). Doctor of Technological Sciences (materials engineering), 2007. Publications: author and coauthor of 25 scientific publications. Research interests: physical-mechanical and thermal-technical characteristics of thermal insulating materials and products. 